Hobson, K. A., and S. Wilson. 2020. The avian conservation crisis, Canada's international record, and the need for a new path forward. Avian Conservation and Ecology 15(2):22. https://doi.org/10.5751/ACE-01756-150222

Copyright (C) 2020 by the author(s). Published here under license by the Resilience Alliance.

Editorial

\title{
The avian conservation crisis, Canada's international record, and the need for a new path forward
}

\author{
Keith A. Hobson ${ }^{1,2}$ and Scott Wilson ${ }^{3}$ \\ ${ }^{1}$ Department of Biology, University of Western Ontario, London, Ontario, Canada, ${ }^{2}$ Environment and Climate Change Canada, \\ Wildlife Research Division, Saskatoon, Saskatchewan, Canada, ${ }^{3}$ Environment and Climate Change Canada, Wildlife Research \\ Division, Ottawa, Ontario, Canada
}

\section{La crise de la conservation des oiseaux, le bilan international du Canada et la nécessité d'une nouvelle voie}

\section{INTRODUCTION}

Avian Conservation and Ecology, is the official publication of the Society of Canadian Ornithologists and so, while we present just the views of the authors, we take this opportunity to focus on Canada's standing internationally when it comes to the conservation of biodiversity in general and avian diversity, in particular. Our brief reflections were inspired primarily by the recent publication of the International Conservation Fund of Canada (ICFC 2020) that presents the case for an expanded role for Canada in stemming global biodiversity loss. That report came as a surprise given Canada's current support on a variety of domestic conservation issues and internationally with respect to both social justice initiatives and wildlife conservation. In stark contrast, this report describes Canada's limited support for the conservation of nature internationally and especially in the highly threatened tropical regions of the world. This ICFC report clearly comes at a time of intense societal upheaval due to the Covid-19 pandemic and the unprecedented catastrophic global declines in biodiversity and rapid increases in extinction rates. Here, we highlight the main messages of the ICFC 2020 report and suggest that, among other initiatives, a recognition that population declines of numerous species of Neotropical migrant birds breeding in Canada, including many of the species listed on the Species at Risk Act (SARA), are inextricably linked to habitat loss and degradation taking place outside our national borders and especially in tropical forests of Central and South America. A renewed focus on full life-cycle conservation of migrant avifauna breeding in Canada and our international obligations for these species provides a win-win opportunity to both increase our effectiveness in recovering migratory birds in decline and help fight global biodiversity loss.

\section{THE ICFC 2020 REPORT}

As detailed in the 2019 Intergovernmental Science-Policy Platform on Biodiversity and Ecosystem Service (IPBES), the sweeping loss of the world's biodiversity, now recognized as the sixth mass extinction (Ceballos et al. 2015), is unprecedented with as many as one million species identified as being at risk of extinction (IPBES 2019). By far, the greatest threats are found in the terrestrial and marine biomes of the tropics. This sweeping tide of biodiversity loss is heedless of national boundaries and has impacts on ecosystems, climate, and human livelihoods far removed from the regions where it occurs. At the time of writing, the dry season in the Amazon and elsewhere in the Neotropics has brought about renewed illegal logging and burning that has sparked international outrage. Governments of several countries in the Organisation for Economic Co-operation and Development (https://stats.oecd.org/Index.aspx?DataSetCode= RIOMARKERS) have responded to such crises over the last decade through contributions to the Bilateral Official Development Assistance Committee (DAC). Canada's bilateral biodiversity-related Official Development Assistance (ODA) to developing countries averaged just Can\$10.4 million (US\$7.9 million) per year (2016-2018). This represents only $4 \%$ of the average of US\$183 million for 28 OECD DAC countries resulting in Canada's ranking of 22 out of 28 nations in per capita terms and 23rd in terms of a percentage of Gross National Income (GNI; Fig. 1). In other words, Canadians pay just US\$0.22 per person, i.e., approximately 28 cents in Can\$, to lower-income countries for protecting the world's wildlife. The leading countries in total contribution, France and Germany, each contributed over a billion US dollars annually representing US\$17.01 and US\$12.80 per person, respectively. Norway, with a resource extraction-based economy similar to Canada's but with a much lower population paid the equivalent of US\$47.80 per person per year to developing countries to fight biodiversity loss.

The ICFC 2020 report recommended that an equitable way to consider how much Canada should be spending internationally on biodiversity conservation should be related to the size of its economy. Canada's economy represents $2 \%$ of the world Gross Domestic product (GDP). If we assume that a midrange estimate to address global biodiversity loss is $\$ 328$ billion annually (CBD High-Level Panel 2014, ICFC 2020), then Canada's 2\% share amounts to US\$6.6 billion. If we then subtract the US\$1.1 billion that Canada spends domestically on biodiversity conservation, we are left with US\$5.5 billion or Can\$7.2 billion. Another 
approach would be for Canada to match the top donor countries of France, Germany, Norway, and Sweden with respect to biodiversity spending relative to GNI; that approach would result in about $\$ 17$ per Canadian. Finally, the ICFC report notes that Norway and Sweden spend about as much on conservation internationally as they do domestically and Germany and France spend about twice as much internationally. Even if Canada followed the Norway/Sweden model, it would amount to about Can $\$ 1.5$ billion internationally annually, compared with the Can\$10.4 million it currently spends.

Fig. 1. Average annual biodiversity-related bilateral Official Development Assistance (ODA) for 2016-2018 by donor nations of the Organisation for Economic Co-operation and Development (OECD) Development Assistance Committee.

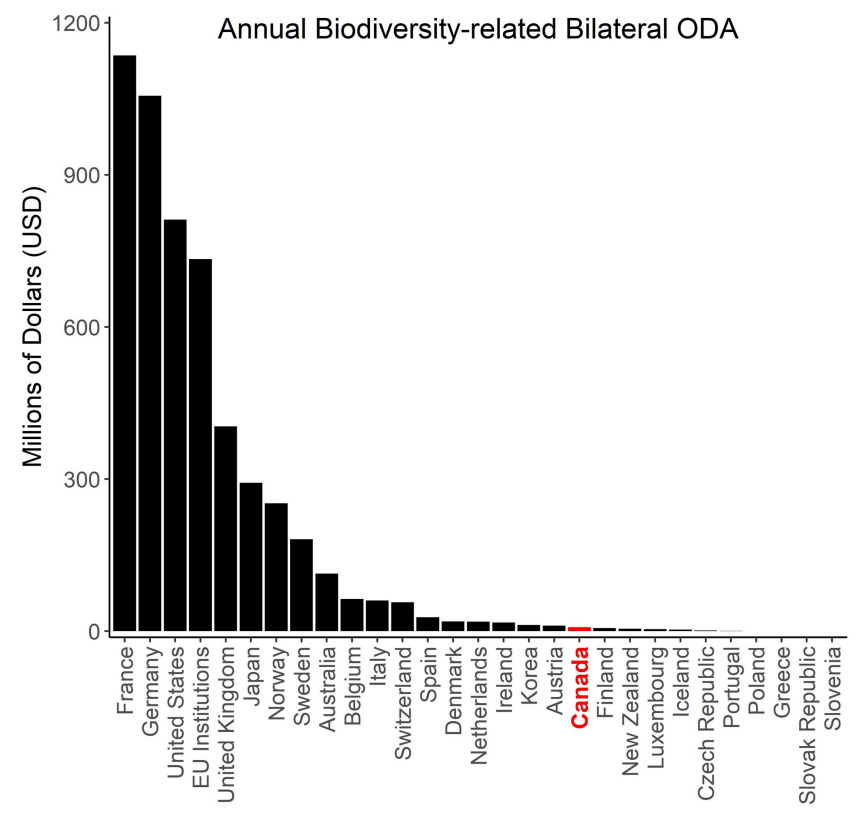

The ICFC 2020 report concludes with the following three recommendations for how Canada can help lower-income countries to protect the world's biodiversity (p. 5):

"

1. Increase international assistance for biodiversity conservation to at least $\$ 650$ million per year-the level of the top tier of biodiversity aid donor countries."

2. Encourage all industrialized countries to commit to substantial support for conservation in developing nations in the post-2020 CBD framework."

3. Focus a substantial portion of aid for climate action on "nature-based climate solutions" in the tropics that provide simultaneous benefits to biodiversity and human well-being.

Additionally, the authors of the ICFC report note that Canada's leadership role can go beyond just spending and could include (1) a call for a moratorium on logging in intact tropical forests, (2) support for restoration of tropical forests, (3) setting up and administering a faunal restoration fund, and (4) calling for an end to commercial trade and exploitation of threatened wildlife globally.

\section{THE MIGRATORY BIRD CONNECTION}

Canada hosts a diverse and impressive breeding avifauna with an estimated 1-3 billion birds breeding in the boreal forest alone (Wells et al. 2014). However, as a northern temperate country, almost three quarters of Canadian breeding species are short- or long-distance migrants that spend only the minority of their annual cycle in Canada. Among long-distance migrants, most winter in Mexico, Central America, the Caribbean, and northern South America with many of these requiring tropical or low- to midelevation temperate forests. According to the 2019 State of Canada's Birds report (NABCI 2019), long-distance migrant songbirds have suffered among the greatest declines of any group of Canadian-breeding birds.

Canada has important legislation concerning migratory birds through the Migratory Bird Convention signed with the United States but this legislation largely deals with the legal take of migratory birds, nests, and their eggs within Canada and the USA Domestically, the Canadian SARA is designed to describe the status of Canada's plants and animals, including birds, and to produce recovery plans to reverse negative population trajectories. Indeed, on the domestic front, Canada compares well internationally for conserving biodiversity (e.g., Waldron et al. 2013, McClanahan and Rankin 2016). For example, Canada's 2018 Budget committed an unprecedented $\$ 1.3$ billion, including $\$ 500$ million over five years toward a Nature Fund, to establish new protected areas and recover threatened species in Canada. In 2019 , the government pledged to protect $25 \%$ of Canada's ocean waters as well as $25 \%$ of Canada's land by 2025 and this number is planned to increase to $30 \%$ by 2030 .

Canada's two main pieces of legislation dealing with the conservation of migratory species, the Migratory Bird Conservation Act and SARA, focus only on the breeding grounds whereas successful conservation actions clearly require consideration of factors influencing populations over the full annual cycle (Marra et al. 2015, Schuster et al. 2019). The need for full annual cycle research and conservation has been recognized for some time in the case of Afro-Palearctic migrants with coordinated efforts across countries to reduce threats (Vickery et al. 2014). Although Canada's domestic spending, both federal and provincial, compares well with that of other countries, the number of species with declining population trends and those being listed under SARA continues to climb, increasing the financial burden associated with protection and conservation measures (Mooers et al. 2010). Although the United States enacted the Neotropical Migratory Bird Conservation Act to address the conservation requirements of migratory bird populations throughout their life cycles, Canada lacks similar legislation or agreements with countries in the Neotropics that "share" our migratory birds. The failure to incorporate conservation actions outside of Canada has been identified as a principal reason underlying low probabilities of reaching recovery targets for migratory species-at-risk (Martin et al. 2018). Although this point seems obvious, there is still almost no 
recognition given to the need for conservation practiced on the nonbreeding grounds. A classic example of this is the fact that in the Andes region of Colombia, substantial areas of midelevation primary forest have been converted to human-modified landscapes (Etter et al. 2008). Of 22 species that breed in the Canadian boreal or eastern hardwood forests and overwinter in the Colombian Andes, 18 are in long-term decline with more than $30 \%$ of the global abundance of this group lost since 1970 (Fig. 2 ). This decline contrasts with a roughly $35 \%$ increase over the same time period for 39 species that remain within Canada year round. Wilson et al. (2018) have demonstrated clearly that factors occurring on the wintering grounds overwhelmingly account for declines of Canada Warbler (Cardellina canadensis), a SARAlisted species in Canada, and that this species is representative of a suite of midelevation Andean forest bird species of concern in that region including Golden-winged Warbler (Vermivora chrysoptera), Cerulean Warbler (Setophaga cerulea), Rosebreasted Grosbeak (Pheucticus ludovicianus), and Swainson's Thrush (Catharus ustulatus). Although considerable time and resources have already gone into recovery efforts for species like the Canada Warbler within Canada, these efforts will not be costeffective in accomplishing their desired goal if focused on a period of the annual cycle that is not contributing to population declines. By properly identifying and targeting efforts to the period under threat we can more efficiently allocate resources to strategies that actually help migratory species-at-risk recover while also enhancing our contribution to protect global biodiversity.

Fig. 2. Long-term (1970-2015) population trends for 39 terrestrial landbirds that remain within Canada year round (blue line) and 22 terrestrial landbirds that breed in Canada and overwinter in South America (black line). Shaded areas around each line represent the $95 \%$ credible interval on the group population trends. Population trends are based on survey information used in the State of Canada's Birds report and are developed using a hierarchical generalized additive model (NABCI 2019). For additional details on the methods, see http://nabci.net/resources/state-of-canadas-birds-2019/.

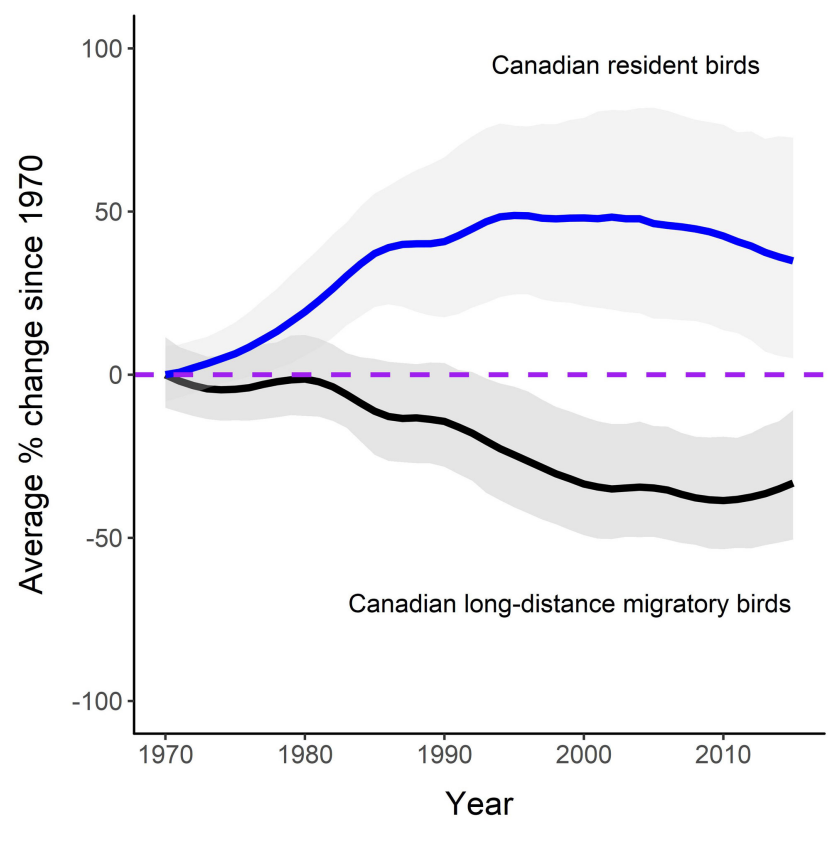

\section{THE PATH AHEAD}

The ICFC 2020 report clearly articulates the need for Canada to dramatically increase its international contributions for the conservation of global biodiversity, especially in tropical regions and has provided Canada with a series of valuable recommendations. These recommendations also link Canada's various commitments to combatting climate change and the extensive revenues to Canadian resource extraction industries operating overseas. We believe that these recommendations also provide Canada with an excellent opportunity to help conserve Canadian breeding birds that winter in the Neotropics. It is clear that the effective conservation of species that spend most of their annual cycle in the Neotropics must involve a coordinated approach to on-the-ground conservation in Latin America and the Caribbean. We believe that such considerations should be incorporated specifically into Canadian SARA recovery plans involving Neotropical migratory birds. Indeed, the current SARA legislation provides an ideal opportunity to pursue future refinements that can better address full life-cycle conservation of listed species and further benefit associated nonlisted species with similar wintering habitat requirements. There is also opportunity for the expansion of governmental and nongovernmental international partnerships focusing on shared species in decline. As an example, the North American Waterfowl Management Plan has been extremely effective in conserving and restoring shared waterfowl species across Canada, the United States, and Mexico over the last 50 or more years. A greater emphasis on partnerships focused on the conservation of nonhunted species that move between North America and the Neotropics could similarly help recover populations of these shared species. The global Convention of Migratory Species (http://www.cms.int/) is one such opportunity. Through the broad recognition of full life cycle conservation and its obligations to conserve biodiversity beyond its borders, Canada could become a world leader in initiating broad-based conservation strategies that seamlessly integrate initiatives within and outside its borders.

Responses to this article can be read online at: https://www.ace-eco.org/issues/responses.php/1756

\section{Acknowledgments:}

We thank Kevin Kardynal and Greg Mitchell for helpful assistance and discussion. Elsie Krebs, Amie Black, and Alex Bond made valuable critical comments on an earlier version of the manuscript.

\section{LITERATURE CITED}

Ceballos, G., P. R. Ehrlich, A. D. Barnosky, A. Garcia, R. M. Pringle, and T. M. Palmer. 2015. Accelerated modern humaninduced species losses: entering the sixth mass extinction. Science Advances 1(5):e1400253. https://doi.org/10.1126/sciadv. 1400253

Convention on Biological Diversity (CBD) High-Level Panel. 2014. Resourcing the Aichi Biodiversity Targets: an assessment of benefits, investments and resource needs for implementing the strategic plan for biodiversity 2011-2020. Second Report of the High-Level Panel on Global Assessment of Resources for 
Implementing the Strategic Plan for Biodiversity 2011-2020. CBD, Montréal, Québec, Canada. [online] URL: https://www. cbd.int/financial/hlp/doc/hlp-02-report-en.pdf

Etter, A., C. McAlpine, and H. Possingham. 2008. Historical patterns and drivers of landscape change in Colombia since 1500: a regionalized spatial approach. Annals of the Association of American Geographers 98:2-23. https://doi.org/10.1080/00045600701733911

Intergovernmental Science-Policy Platform on Biodiversity and Ecosystem Services (IPBES). 2019. Summary for policymakers of the global assessment report on biodiversity and ecosystem services of the Intergovernmental Science-Policy Platform on Biodiversity and Ecosystem Services. IPBES Secretariat, Bonn, Germany.

International Conservation Fund of Canada (ICFC). 2020. Tropical nature needs us: an expanded role for Canada in stemming global biodiversity loss. ICFC, Chester, Nova Scotia, Canada.

Marra, P. P., E. B. Cohen, S. R. Loss, J. E. Rutter, and C. M. Tonra. 2015. A call for full annual cycle research in animal ecology. Biology Letters 11(8):20150552. http://dx.doi.org/10.1098/ rsbl.2015.0552

Martin, T. G., L. Kehoe, C. Mantyka-Pringle, I. Chades, S. Wilson, R. G. Bloom, S. K. Davis, R. Fisher, J. Keith, K. Mehl, B. Prieto Diaz, M. E. Wayland, T. I. Wellicome, K. P. Zimmer, and P. A. Smith. 2018. Prioritizing recovery funding to maximize conservation of endangered species. Conservation Letters 11: e12604. https://doi.org/10.1111/conl.12604

McClanahan, T. R., and P. S. Rankin. 2016. Geography of conservation spending, biodiversity, and culture. Conservation Biology 30:1089-1101. https://doi.org/10.1111/cobi.12720

Mooers, A. O., D. F. Doak, C. S. Findlay, D. M. Green, C. Grouios, L. L. Manne, A. Rashvand, M. A. Rudd, and J. Whitton. 2010. Science, policy, and species at risk in Canada. Bioscience 60:843-849. https://doi.org/10.1525/bio.2010.60.10.11

North American Bird Conservation Initiative Canada (NABCI). 2019. The state of Canada's birds 2019. Environment and Climate Change Canada, Ottawa, Ontario, Canada. [online] URL: http:// nabci.net/resources/state-of-canadas-birds-2019/

Schuster, R., S. Wilson, A. D. Rodewald, P. Arcese, D. Fink, T. Auer, and J. R. Bennett. 2019. Optimizing the conservation of migratory species over their full annual cycle. Nature Communications 10:1754. https://doi.org/10.1038/s41467-019-09723-8

Vickery, J. A., S. R. Ewing, K. W. Smith, D. J. Pain, F. Bairlein, J. Škorpilová, and R. D. Gregory. 2014. The decline of AfroPalearctic migrants and an assessment of potential causes. Ibis 156:1-22. https://doi.org/10.1111/ibi.12118
Waldron, A., A. O. Mooers, D. C. Miller, N. Nibbelink, D. Redding, T. S. Kuhn, J. T. Roberts, and J. L. Gittleman. 2013. Targeting global conservation funding to limit immediate biodiversity declines. Proceedings of the National Academy of Sciences 110:12144-12148. https://doi.org/10.1073/pnas. 1221370110

Wells, J., D. Childs, F. Reid, K. Smith, M. Darveau, and V. Courtois. 2014. Boreal birds need half: maintaining North America's bird nursery and why it matters. Boreal Songbird Initiative, Seattle, Washington, USA, Ducks Unlimited Inc., Memphis, Tennessee, USA, and Ducks Unlimited Canada, Stonewall, Manitoba, Canada.

Wilson, S., J. F. Sarraco, R. Krikun, D. T. T. Flockhart, C. M. Godwin, and K. R. Foster. 2018. Drivers of demographic decline across the annual cycle of a threatened migratory bird. Scientific Reports 8:7316. https://doi.org/10.1038/s41598-018-25633-z
Sponsored by the Society of Canadian Ornithologists and Birds Canada

Parrainée par la Société des ornithologistes du Canada et Oiseaux Canada

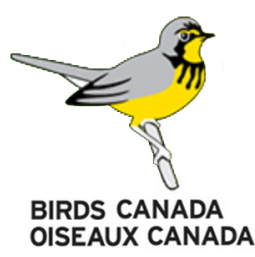

